Utah State University

DigitalCommons@USU

$\mathrm{Ca}$

Bee Lab

5-1-1909

\title{
Two New Bees of the Genus Perdita, Visiting Baileya in New Mexico
}

T. D. A. Cockerell

University of Colorado

Follow this and additional works at: https://digitalcommons.usu.edu/bee_lab_ca

Part of the Entomology Commons

\section{Recommended Citation}

Cockerell, T. D. A., "Two New Bees of the Genus Perdita, Visiting Baileya in New Mexico" (1909). Ca. Paper 426.

https://digitalcommons.usu.edu/bee_lab_ca/426

This Article is brought to you for free and open access by the Bee Lab at DigitalCommons@USU. It has been accepted for inclusion in $\mathrm{Ca}$ by an authorized administrator of DigitalCommons@USU. For more information, please contact digitalcommons@usu.edu.

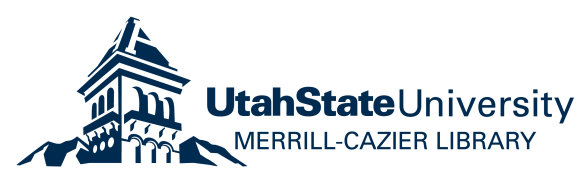




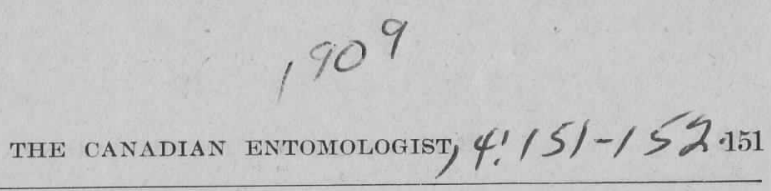

Pupa bright orange-scarlet, with a pair of prominent anterior projections.

Female $2280 \mu$ long, of which $500 \mu$ is ovipositor; antennæ 16 -jointed, the joints practically sessile; length of antennæ about $730 \mu$; wing $1530 \mu$ long (but the $q$ varies in size, a small one having the wing only 1360 , a large one as much as 1785 ); thorax small, only $425 \mu$ long. Thorax black or almost; legs and antennæ pale; abdomen in life bright scarlet. Wings normal; angle formed by third vein, and margin above scarcely short of a right angle; distal part of third vein faint. Fringe very long, some of the hairs exceeding $170 \mu$.

Male.-Differs by the longer legs and the cylindrical brown abdomen; claspers stout, obtuse. The femora measure in $\mu$ : anterior, 830 ; middle, 800 ; hind, I000. Antennæ 16 -jointed; middle joints with bulb about $6 \circ \mu$, and pedicel 40 ; the hairs on bulb about r 40 . Scutellum prominent in both sexes.

In Dr. Felt's table (N. Y. State Mus. Bull, I 24) it runs to the group of $R$. antennarice and $R$. alticola, but is distinct from these. $R$. alticola is common in Colorado, making a quite different sort of gall, on Artemisia Canadensis.

Another new species of Rhopalomyia, collected at Boulder, will be described by Dr. Felt.

\section{TWO NEW BEES OF THE GENUS PERDITA, VISITING BAILEYA IN NEW MEXICO. \\ BY T. D. A. COCKERELL, BOULDER, COLORADO.}

Perdita baileya, n. sp.

f.-Length, about $61 / 2 \mathrm{~mm}$; head and thorax shining dark bluishgreen (vertex dull and yellower green), with copious white hair ; eyes dull pea-green; cheeks unarmed; mandibles (except tips), labrum, clypeus (except the usual dots, and more or less of the upper edge) and lateral marks all creamy-white; lateral marks filling the space between clypeus and eye below, but ending abruptly just below level of upper edge of clypeus, except for a very fine streak which runs a short distance up the orbital margin; antennæ pale yellow basally and orange apically, the scape black above, and the first few flagellar joints more or less ringed with blackish above; upper edge of prothorax, tubercles, and spot on the hyaline tegulæ, cream-colour; pleura without light markings ; wings milky hyaline, stigma light yellow, nervures white; marginal cell with the poststigmatal portion May, Igog 
much the longest; second recurrent nervure evanescent; legs with much white hair ; femora black (anterior ones metallic behind), with the apices yellow, and a broad light yellow band in front on anterior and middle pair ; anterior and middle tibiæ yellow, with a large dari patch behind; hind tibiæ dark, with the base and the inner side light yellow; tarsi yellowish-white, hind ones more or less darkened and reddened; abdomen black, with white bands, which are partly or wholly interrupted sublaterally; band on first segment twice as broad at sides as in middle, but sublaterally reduced to a hardly visible line by a rounded invasion of the black; bands on second and third excavated in the middle anteriorly, and with a large black spot on each side sublaterally; bands on fourth and fifth deeply emarginate, almost interrupted, sublaterally; that on sixth reduced to a hardly visible marginal line; venter black, with obscure linear white bands. In my table in Proc. Phila. Acad, I 896 , this runs to 64 , and runs out because of the conspicuous white abdominal bands. It is considerably larger than $P$. albovittata, Ckll., and $P$. callicerata, Ckll., which also visit the Baileya, but is related to them, and combines some of their characters. There is some resemblance to $P$. perpulchra, Ckll., but in that insect the male has the face all light.

Hab.-Mesilla, New Mexico, at flowers of Baileya multiradiata, June 30, 1897 (Cockerell). Two males.

Perdita callicerata, var. leucura, n. var.

9.-Length slightly over $5 \mathrm{~mm}$; head and thorax very hairy; clypeus white, with the usual dots; lateral marks white, tapering above, to end in sharp points on orbital margin near lower ends of facial foveæ (a little above level of antennæ) ; antennæ coloured as usual, the flagellum largely orange; abdomen cream-colour, with sepia-brown markings, consisting of a brown basal area and (separated only by a fine line, and not reaching the lateral margins) a transverse band on first segment, three spots on second segment, usually two on third, and fine basal lines on second to fourth; venter pale. Wings and legs as in P. callicerata, Ckll.

This might be described as a $P$. callicerata, with the abdomen and lateral face-marks of $P$. pallidior, Ckll. The broad face and the hairiness are entirely as in $P$. callicerata, and readily distinguish it from $P$. pallidior and $P$. mentzeliarum. Is the insect perhaps a hybrid?

Hab.-Mesilla, New Mexico, at flowers of Baileya multiradiata, June 30,1897 (Cockerell). Three females, flying with $P$. baileya and $P$. callicerata. 